九州大学学術情報リポジトリ

Kyushu University Institutional Repository

\title{
Study on Performance and Environmental Impact of Supermarket Refrigeration System in Japan
}

Is lam, Md. Ami rul

Kyushu University Program for Leading Graduate School, Green Asia Education Center, IGSES, Kyushu University

Pal, Animesh

International Institute for Carbon-Neutral Energy Research, Kyushu University

Kyaw, Thu

Kyushu University Program for Leading Graduate School, Green Asia Education Center, IGSES, Kyushu University

Saha, Bidyut Baran

Kyushu University Program for Leading Graduate School, Green Asia Education Center, IGSES, Kyushu University

https://doi.org/10.5109/2321014

出版情報 : Evergreen. 6 (2)，pp.168-176，2019-06. 九州大学グリーンテクノロジー研究教育センター バージョン：

権利関係 : 


\title{
Study on Performance and Environmental Impact of Supermarket Refrigeration System in Japan
}

\author{
Md. Amirul Islam ${ }^{1,2,4, *}$, Animesh $\mathrm{Pal}^{2}$, Kyaw Thu ${ }^{1,2}$, Bidyut Baran Saha ${ }^{1,2,3}$ \\ ${ }^{1}$ Kyushu University Program for Leading Graduate School, Green Asia Education Center, IGSES, \\ Kyushu University, Kasuga-koen 6-1, Kasuga-shi, Fukuoka 816-8580, Japan \\ ${ }^{2}$ International Institute for Carbon-Neutral Energy Research (WPI-I'CNER), Kyushu University, \\ 744 Motooka, Nishi-ku, Fukuoka 819-0395, Japan \\ ${ }^{3}$ Mechanical Engineering Department, Kyushu University, 744 Motooka, Nishi-ku, Fukuoka 819-0395, Japan \\ ${ }^{4}$ Bangabandhu Sheikh Mujibur Rahman Science \& Technology University, Gopalganj 8100, Bangladesh \\ *Author to whom correspondence should be addressed, \\ E-mail: toha_apece@yahoo.com \\ (Received March 26, 2019; accepted June 17, 2019).

\begin{abstract}
Season change significantly influences the cooling requirement and electricity consumption of supermarket refrigeration systems. Monthly total equivalent warming impact (TEWI) and system performance parameters (COP, discharge gas temperature-pressure, work of compression etc.) have been assessed for a typical supermarket refrigeration system of Tokyo, Japan. A medium temperature $\left(-7^{\circ} \mathrm{C}, 200 \mathrm{~kW}\right)$ and a low temperature $\left(-25^{\circ} \mathrm{C}, 50 \mathrm{~kW}\right)$ cooling load have been considered for the assessment. The results indicate that the monthly lowest TEWI is found in February and highest is in July for single cycle refrigeration system. The possibility of cascading for low temperature cooling load is also considered for smooth operation and longer lifetime. TEWI of past twenty years is presented to give an overview of how much global warming is originated by a mid-size supermarket.
\end{abstract}

Keywords: climate, COP, GWP, Japan, R404A, R410A, supermarket, TEWI.

\section{Introduction}

$\mathrm{R} 410 \mathrm{~A}$ and $\mathrm{R} 404 \mathrm{~A}$ refrigerants are introduced in the 1990s to fill up the void created by the phase-out of ozonedepleting CFC refrigerants such as R12 and R5021). R410A is commonly used in stationary refrigeration units, moveable and split air-conditioning systems. Moreover, applications of R404A are in the field of commercial refrigeration systems and freezers ${ }^{2,3)}$. Supermarkets have refrigerated display cabinets for the customers to show their products such as ice-cream, beverage, vegetable, frozen fish, frozen meat and so on. They also have warehouses to store these products. The refrigeration temperature (MT or LT) differs depending on the products. R410A and R404A refrigerants are widely used in the supermarket refrigeration systems ${ }^{4}$.

According to the statistics conducted by the supermarket society in February 2019, there are about 20,758 supermarkets in Japan and 2,601 of them are located in Tokyo ${ }^{5}$. These supermarkets consume a tremendous amount of electricity. More than $80 \%$ of this electricity is generated from fossil fuel sources ${ }^{6}$. The burning of fossil fuel releases a huge amount of $\mathrm{CO}_{2}$ to the environment. Hence, supermarkets indirectly contribute a lot to global warming by using electricity.

Table 1. Properties of the selected refrigerants ${ }^{7-9)}$

\begin{tabular}{|c|c|c|}
\hline & $\mathrm{R} 410 \mathrm{~A}$ & $\mathrm{R} 404 \mathrm{~A}$ \\
\hline $\mathrm{GWP}_{100}$ & 2088 & 3922 \\
\hline Normal boiling point $\left({ }^{\circ} \mathrm{C}\right)$ & -60.9 & -46.6 \\
\hline Critical temperature $\left({ }^{\circ} \mathrm{C}\right)$ & 71.342 & 72.12 \\
\hline Critical pressure (MPa) & 4.901 & 3.735 \\
\hline ASHRAE safety group & A1 & A1 \\
\hline Composition & $\begin{array}{ll}\text { R32 } & (50 \%) \\
\text { R125 } & (50 \%)\end{array}$ & $\begin{array}{ll}\text { R125 } & (44 \%) \\
\text { R134a } & (4 \%) \\
\text { R143a } & (52 \%)\end{array}$ \\
\hline Molecular mass (g/mol) & 72.58 & 96.70 \\
\hline
\end{tabular}

Supermarket refrigeration systems are large in size and require a lot of refrigerant charging ${ }^{10)}$. The actual initial charging amount depends on the evaporator cooling capacity, condenser capacity, evaporator and condenser heat exchanger size, heat transfer coefficients, operating 
conditions etc. Approximately, the required refrigerant amount can be expressed in terms of cooling capacity. For commercial/supermarket refrigeration systems, the amount (in $\mathrm{kg}$ ) is 2 to 3.4 times of the cooling load $(\mathrm{kW})^{11)}$. The compressor and condenser sections operate at a high temperature and pressure than the atmospheric. Although the compressor is hermetically sealed, a significant amount of leakage (about 20\%) can occur from joints and seals, mechanical failure or during servicing ${ }^{12,13)}$. This leakage will lead to performance degradation and will increase energy consumption ${ }^{14,15}$. Moreover, the leaked refrigerants have high GWP (Table 1) which will eventually contribute directly to the global warming ${ }^{16)}$.

The exterior temperature is directly related to the condensation temperature of the vapour compression system. A high condensation temperature in summer results lower COP, higher discharge temperature and pressure, high compression ratio and low isentropic efficiency. Hence, the performance of a basic (single refrigeration cycle) refrigeration system degrades and TEWI also increases. A cascaded system can significantly improve the lifetime of a refrigeration system in such situations ${ }^{17,18)}$. Contrarily, the performance and lifetime are better and TEWI is also smaller for lower temperature outdoor conditions. In Tokyo, sometimes the temperature reaches below $0{ }^{\circ} \mathrm{C}$ during winter and reaches around $40{ }^{\circ} \mathrm{C}$ in summer. Average temperature variation of the past few years (Table 2) implies that the refrigeration systems perform well in January/February and the load is extreme during July/August.

Table 2. Temperature $\left({ }^{\circ} \mathrm{C}\right)$ of past few years in Tokyo ${ }^{19)}$.

\begin{tabular}{llllll}
\hline & 1998 & 2003 & 2008 & 2013 & 2018 \\
\hline Jan & 6.20 & 5.50 & 5.90 & 5.50 & 4.70 \\
\hline Feb & 7.70 & 6.40 & 5.50 & 6.20 & 5.40 \\
\hline Mar & 8.70 & 8.70 & 10.70 & 12.10 & 11.50 \\
\hline Apr & 13.40 & 15.10 & 14.70 & 15.20 & 17.00 \\
\hline May & 18.10 & 18.80 & 18.50 & 19.80 & 19.80 \\
\hline Jun & 21.70 & 23.20 & 21.30 & 22.90 & 22.40 \\
\hline Jul & 22.50 & 22.80 & 27.00 & 27.30 & 28.30 \\
\hline Aug & 24.80 & 26.00 & 26.80 & 29.20 & 28.10 \\
\hline Sep & 22.90 & 24.20 & 24.40 & 25.20 & 22.90 \\
\hline Oct & 17.50 & 17.80 & 19.40 & 19.80 & 19.10 \\
\hline Nov & 14.10 & 14.40 & 13.10 & 13.50 & 14.00 \\
\hline Dec & 8.50 & 9.20 & 9.80 & 8.30 & 8.30 \\
\hline
\end{tabular}

In this research work, performance and environmental impact of a typical supermarket refrigeration system have been assessed. For the year 2018, monthly weather variation of Tokyo has been considered. Since the weather in summer is very high and work of compression is huge, a cascaded system for LT unit has also been assessed. State diagrams, COP, discharge temperature and pressure, compression ratio, TEWI for both single cycle and cascaded refrigeration systems have been presented.

\begin{tabular}{|c|c|c|}
\hline \multicolumn{3}{|c|}{ Nomenclature } \\
\hline \multicolumn{3}{|l|}{ Symbols } \\
\hline $\mathrm{COP}$ & coefficient of performance & {$[-]$} \\
\hline $\mathrm{E}$ & electricity consumption & {$[\mathrm{kWh}]$} \\
\hline GHG & greenhouse gas & {$[-]$} \\
\hline $\mathrm{GWP}_{100}$ & $\begin{array}{l}\text { global warming potential ( } 100 \\
\text { years integration) }\end{array}$ & {$\left[\mathrm{kg}-\mathrm{CO}_{2}\right.$ eq. $]$} \\
\hline h & enthalpy & {$\left[\mathrm{kJ} \mathrm{kg}^{-1}\right]$} \\
\hline HT & high temperature & {$\left[{ }^{\circ} \mathrm{C}\right]$} \\
\hline $\mathrm{kWh}$ & kilowatt-hour & {$[-]$} \\
\hline $\mathrm{L}$ & leakage rate per year & {$[\%]$} \\
\hline LT & low temperature & {$\left[{ }^{\circ} \mathrm{C}\right]$} \\
\hline MT & medium temperature & {$\left[{ }^{\circ} \mathrm{C}\right]$} \\
\hline $\mathrm{P}$ & pressure & {$[\mathrm{kPa}]$} \\
\hline Q & capacity & {$[\mathrm{kW}]$} \\
\hline $\mathrm{S}$ & entropy & {$\left[\mathrm{kJ} \mathrm{kg}^{-1} \mathrm{~K}^{-1}\right]$} \\
\hline $\mathrm{t}$ & tonne & {$[-]$} \\
\hline $\mathrm{T}$ & temperature & {$\left[{ }^{\circ} \mathrm{C}\right]$} \\
\hline TEWI & $\begin{array}{l}\text { total equivalent warming } \\
\text { impact }\end{array}$ & {$\left[\mathrm{t}-\mathrm{CO}_{2}\right.$ eq. $]$} \\
\hline \multicolumn{3}{|c|}{ Greek letters } \\
\hline$\eta$ & efficiency & {$[\%]$} \\
\hline$\dot{\mathrm{m}}$ & mass flow rate & {$\left[\mathrm{kg} \mathrm{h}^{-1}\right]$} \\
\hline$\varepsilon$ & $\begin{array}{l}\mathrm{CO}_{2} \text { emission factor for per } \\
\text { unit electricity generation }\end{array}$ & $\begin{array}{l}{\left[\mathrm{kg}-\mathrm{CO}_{2}\right.} \\
\text { eq. } / \mathrm{kWh}]\end{array}$ \\
\hline \multicolumn{3}{|c|}{ Subscripts } \\
\hline mon_avg & monthly average temperature & \\
\hline $\mathrm{c}$ & cooling load & \\
\hline com & compressor & \\
\hline con & condenser & \\
\hline dis & discharge gas & \\
\hline eva & evaporator & \\
\hline isen & isentropic & \\
\hline $\mathrm{p}$ & power & \\
\hline sub & subcooling & \\
\hline suc & suction gas & \\
\hline sup & superheating & \\
\hline
\end{tabular}




\section{Calculation procedure}

\subsection{Operation principle}

A simple vapour compression system with subcooling and superheating is shown in Fig. 1. Corresponding P-h diagram and the state of refrigerant in a refrigeration cycle is shown in Fig. 2. In this cycle, when the refrigerant leaves the evaporator (point a), a certain amount of superheat is applied to prevent damage and to increase the efficiency of the system. The refrigerant is then fed to the suction line of the compressor (point $a^{\prime}$ ). Vapour refrigerant discharges from the compressor (point $b "$ ") after a non-isentropic compression. The hot vapour refrigerant is then cooled and condensed in the condenser by an isobaric process. Released refrigerant from the condenser (point $\mathrm{c}$ ) is subcooled to ensure that all the refrigerant is in the liquid state. After subcooling (point $c^{\prime}$ ), the refrigerant is collected into a reservoir. The refrigerant then goes through an expansion device, enter into the evaporator (point $\mathrm{d}^{\prime}$ ), evaporate isobarically until it reaches evaporator exhaust (point a) and the cycle continues to repeat.

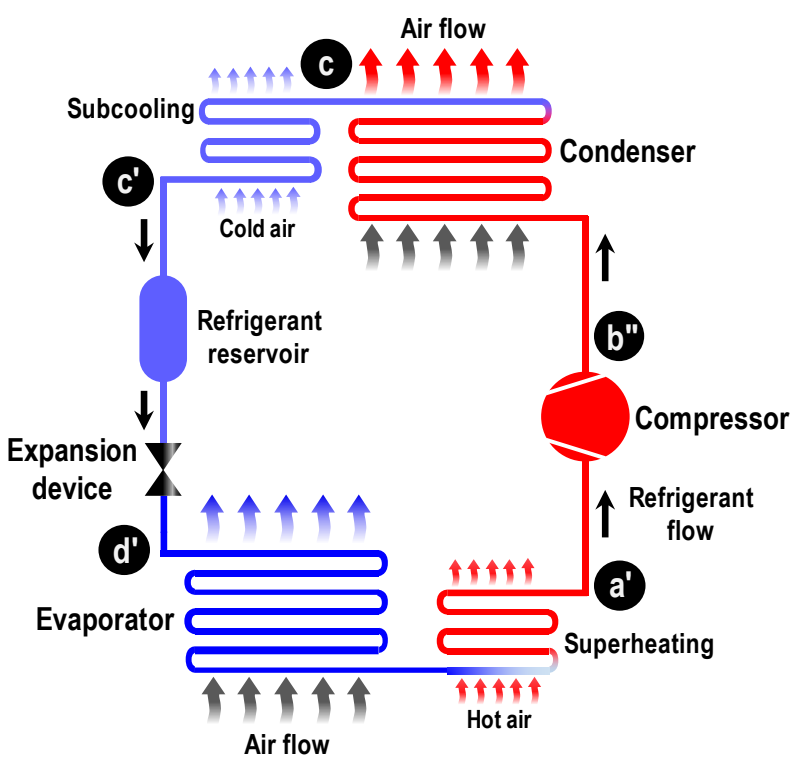

Fig. 1: A simple vapor compression refrigeration system.

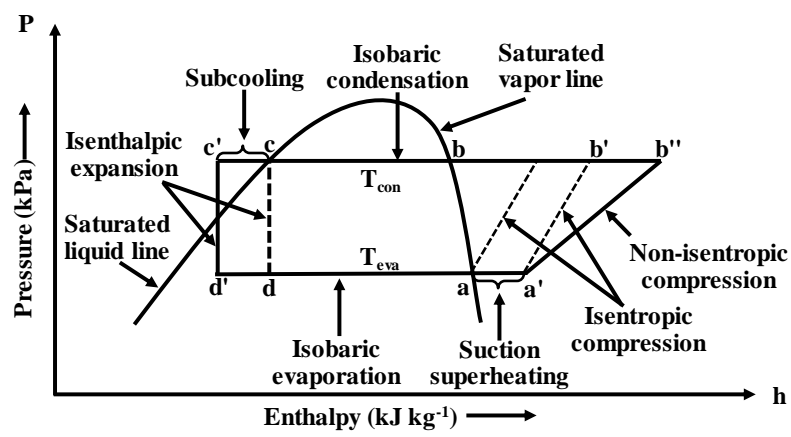

Fig. 2: A typical refrigeration cycle.
In a refrigeration cycle, the refrigerant encounter isobaric, isentropic, non-isentropic and isenthalpic processes as shown in Fig. 2. The following set of equations can be written from the state diagrams.

$P_{d^{\prime}}=P_{d}=P_{a}=P_{a^{\prime}}$

$P_{b^{\prime \prime}}=P_{b^{\prime}}=P_{b}=P_{c}=P_{c^{\prime}}$

$T_{a}=T_{\text {eva }}$

$T_{a^{\prime}}=T_{\text {eva }}+T_{\text {sup }}$

$h_{c^{\prime}}=h_{d^{\prime}}$

$S_{a^{\prime}}=S_{b^{\prime}}$

$T_{\text {con }}=T_{\text {amb }}+T_{\text {split }}$

$T_{b}=T_{c}=T_{c o n}$

$T_{c^{\prime}}=T_{\text {con }}-T_{\text {sub }}$

$\eta_{i s e n}=\frac{h_{b^{\prime}}-h_{a^{\prime}}}{h_{b^{\prime \prime}}-h_{a^{\prime}}}$

Here $\mathrm{P}, \mathrm{T}, \mathrm{S}$ and $\mathrm{h}$ represent the pressure, temperature, entropy and enthalpy at a particular point denoted in the subscript.

\subsection{System description}

A supermarket has numerous refrigerated display cabinets to show various products for the customers. Fish, meat, beverage, ice-cream, and other products are kept in separate cabinets because: (i) preservation temperature of each product is different, (ii) isolate the products so that the smell of one product do not affect another, (iii) it is convenient for the consumers to locate a specific product. Compressors and other electrical equipment might generate louder noise and hence, those are kept in a separate room. Condensers are usually kept in the roof top for efficient functionality. The operation is explained in our previous article ${ }^{20)}$.

\subsection{Assumptions and considerations}

Operating conditions and assumptions for the assessment are summarized in Table 3 . The assessment is performed for two types of cooling load. In general, the amount of MT cooling load is larger than the LT cooling load.

Since the average monthly temperature fluctuates, condensation temperature also varies over the year. A constant temperature difference is considered between outdoor and condensation temperature which is defined as condenser split. 
A certain degree of superheating is considered to ensure that the liquid refrigerant is completely evaporated before it reaches the suction line of the compressor. Likewise, subcooling is performed after condenser to confirm that the refrigerant is completely liquified before entering the expansion device.

Table 3. Operating conditions and assumptions.

\begin{tabular}{|c|c|}
\hline \multicolumn{2}{|l|}{ Common parameters } \\
\hline $\mathrm{T}_{\text {con_split }}$ & $10^{\circ} \mathrm{C}$ \\
\hline $\begin{array}{l}\text { GWP for electricity } \\
\text { generation in Japan, } \varepsilon\end{array}$ & $0.518\left(\mathrm{~kg}-\mathrm{CO}_{2} / \mathrm{kWh}\right)^{21)}$ \\
\hline System runtime & 12 hours/day \\
\hline $\begin{array}{l}\text { Initial refrigerant } \\
\text { charging amount }\end{array}$ & $\begin{array}{r}2 \mathrm{~kg} \text { for per } \mathrm{kW} \\
\text { cooling load }^{11)}\end{array}$ \\
\hline \multicolumn{2}{|l|}{ MT cooling load } \\
\hline Refrigerant & R410A \\
\hline $\mathrm{Q}_{\mathrm{c}, \mathrm{MT}}$ & $200 \mathrm{~kW}$ \\
\hline $\mathrm{T}_{\text {eva,MT }}$ & $-7^{\circ} \mathrm{C}$ \\
\hline $\mathrm{T}_{\text {con }}$ & $\left(\mathrm{T}_{\text {mon_avg }}+\mathrm{T}_{\text {con_split }}\right){ }^{\circ} \mathrm{C}$ \\
\hline $\mathrm{T}_{\text {sup }}$ & $5^{\circ} \mathrm{C}$ \\
\hline $\mathrm{T}_{\text {sub }}$ & $3{ }^{\circ} \mathrm{C}$ \\
\hline$\eta_{\text {isen,MT }}$ & $70 \%$ \\
\hline Annual leakage rate & $15 \%$ \\
\hline \multicolumn{2}{|l|}{ Basic LT cooling load } \\
\hline Refrigerant & $\mathrm{R} 404 \mathrm{~A}$ \\
\hline $\mathrm{Q}_{\mathrm{c}, \mathrm{LT}}$ & $50 \mathrm{~kW}$ \\
\hline $\mathrm{T}_{\mathrm{eva}, \mathrm{LT}}$ & $-25^{\circ} \mathrm{C}$ \\
\hline $\mathrm{T}_{\mathrm{con}}$ & $\left(\mathrm{T}_{\text {mon_avg }}+\mathrm{T}_{\text {con_split }}\right){ }^{\circ} \mathrm{C}$ \\
\hline $\mathrm{T}_{\text {sup }}$ & $5^{\circ} \mathrm{C}$ \\
\hline $\mathrm{T}_{\mathrm{sub}}$ & $3{ }^{\circ} \mathrm{C}$ \\
\hline$\eta_{\text {isen,LT }}$ & $55 \%$ \\
\hline Annual leakage rate & $20 \%$ \\
\hline \multicolumn{2}{|l|}{ Cascaded LT cooling load } \\
\hline Refrigerant (both stage) & R404A \\
\hline $\mathrm{Q}_{\mathrm{c}, \mathrm{LT}}$ & $50 \mathrm{~kW}$ \\
\hline $\mathrm{Q}_{\mathrm{c}, \mathrm{HT}}($ calculated $)$ & $59.91 \mathrm{~kW}$ \\
\hline $\mathrm{T}_{\text {eva_LT_stage }}$ & $-25^{\circ} \mathrm{C}$ \\
\hline $\mathrm{T}_{\text {eva_HT_stage }}$ & $-10^{\circ} \mathrm{C}$ \\
\hline $\mathrm{T}_{\text {con_LT_stage }}$ & $-5^{\circ} \mathrm{C}$ \\
\hline $\mathrm{T}_{\text {con_HT_stage }}$ & $\left(\mathrm{T}_{\text {mon_avg }}+\mathrm{T}_{\text {con_split }}\right){ }^{\circ} \mathrm{C}$ \\
\hline $\mathrm{T}_{\text {sup }}$ (both stage) & $5^{\circ} \mathrm{C}$ \\
\hline $\mathrm{T}_{\text {sub }}$ (both stage) & $3{ }^{\circ} \mathrm{C}$ \\
\hline$\eta_{\text {isen }}($ both stage $)$ & $70 \%$ \\
\hline Annual leakage rate (botl & $15 \%$ \\
\hline
\end{tabular}

Isentropic efficiency decreases when the compression ratio is higher and it operates at a high temperature condition. Hence, a lower isentropic efficiency is considered for the LT cooling load.

A higher amount of leakage occurs when discharge gas pressure is high. Thus, different leakage rate is considered (Table 3) for single cycle R410A and R404A refrigeration systems, respectively. Moreover, the leakage rate for both the cycles of the cascaded system can be considered similar due to a smaller compression ratio.

In Japan, the most share of the electricity generation comes from gas $(39.2 \%)$, coal $(33.7 \%)$ and oil $(8.2 \%)$. Other sources are hydro $(8.2 \%)$, solar PV $(4.9 \%)$, waste $(1.8 \%)$, nuclear $(1.7 \%)$, biofuels $(1.4 \%)$, wind $(0.6 \%)$, and geothermal $(0.2 \%)^{6}$. Combined $\mathrm{CO}_{2}$ emission factor for per unit electricity generation is $0.518 \mathrm{~kg}^{21}$.

A supermarket in Japan is usually open about 12 hours a day. However, the refrigerator cases and storehouse always contain the products and run 24 hours a day. When the refrigerated space reaches the set temperature, the compressor automatically turns off. Hence, the system runtime is considered 12 hours a day. To simplify the calculation, the initial refrigerant charging amount is considered two times of the cooling load.

\subsection{System performance}

Theoretical maximum COP of the system is denoted as Carnot COP and can be expressed by the following equation,

$$
C O P_{\text {carnot }}=\frac{273.15+T_{\text {eva }}}{T_{c o n}-T_{\text {eva }}}
$$

A real system has losses in various sections and the actual COP is lower than $\mathrm{COP}_{\text {carnot. }}$ The ratio of cooling load and work of compression is the practical COP of the system which can be calculated by the following equation.

$$
C O P=\frac{h_{a^{\prime}}-h_{d^{\prime}}}{h_{b^{\prime \prime}}-h_{a^{\prime}}}
$$

Electric power consumption is dependent on the COP of and can be determined by the following equation,

$$
E_{p}=\frac{Q_{c}}{C O P}
$$

The mass flow rate of the refrigerant can be calculated by the following equation,

$$
\dot{m}=\frac{h_{a^{\prime}}-h_{d^{\prime}}}{Q_{c}}
$$

The performance of a system can be confirmed by the equations (11) - (14) and discharge gas temperature/ pressure, compression ratio. All these parameters can be obtained from assumptions and state diagrams. 


\subsection{Environmental impact}

Supermarkets contribute to global warming by emitting greenhouse gases (GHG). This emission can occur indirectly and directly. Since the electricity generation sources discharge GHG, indirect emission occurs due to the electricity consumption of the refrigeration system. Moreover, direct emission happens due to the refrigerant leakage from joints, piping or during servicing/maintenance ${ }^{20)}$. The TEWI can be calculated from direct and indirect emissions for a year by the following equation:

$$
T E W I=\underbrace{(G W P \times L)}_{\begin{array}{c}
\text { Direct emission for } \\
\text { refrigerant leakage }
\end{array}}+\underbrace{(E \times \varepsilon)}_{\begin{array}{c}
\text { Indirect emission for } \\
\text { electricity consumption }
\end{array}}
$$

Here, L, E and $\varepsilon$ represents the refrigerant leakage rate, electricity consumption, and $\mathrm{CO}_{2}$ emission factor for each $\mathrm{kWh}$ of electricity generation, respectively.

\section{Results and discussion}

In 2018, the coldest month of winter was January and hottest month was July. Fig. 3, Fig. 4 and Fig. 5 illustrate

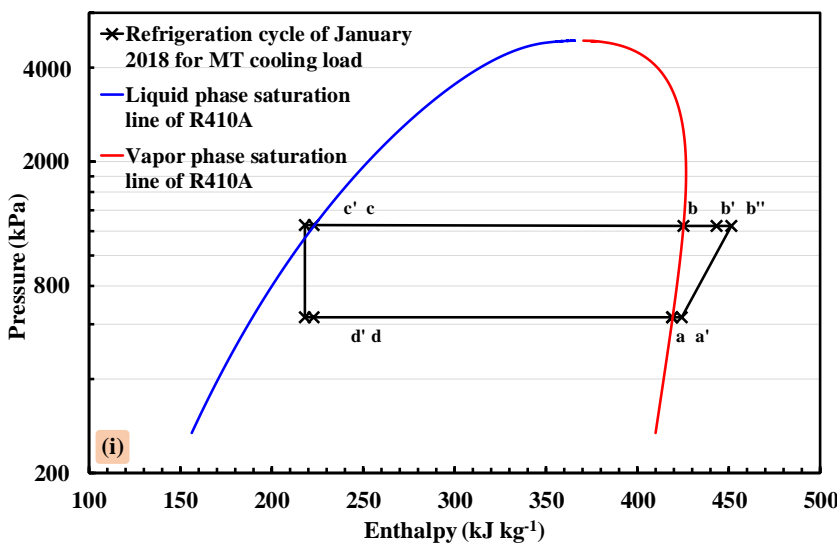

the P-h diagram and refrigeration cycle for simple and cascaded refrigeration cycles during coldest winter and hottest summer for both MT and LT cooling load. For the readers convenience, we have included the corresponding T-s plots in the appendix section. Suction gas temperature and pressure at compressor inlet (point a' of the T-s and P$\mathrm{h}$ diagrams) for the discussed systems are summarized in Table 4. Discharge gas temperature $\left(\mathrm{T}_{\mathrm{dis}}\right)$ and pressure (point $\mathrm{b}$ " of the T-s and P-h diagrams) from compressor outlet are compared in Fig. 6 and Fig. 7. $T_{\text {dis }}$ is relatively higher for R404A than R410A. However, $\mathrm{P}_{\text {dis }}$ is lower for $\mathrm{R} 404 \mathrm{~A}$ due to the thermodynamic property difference.

Table 4. Suction gas property at compressor inlet

\begin{tabular}{|c|c|c|c|c|c|}
\hline \multicolumn{2}{|l|}{ System } & Refrigerant & $\begin{array}{l}\mathrm{T}_{\text {eva }} \\
\left({ }^{\circ} \mathrm{C}\right)\end{array}$ & $\begin{array}{l}\mathrm{T}_{\text {suc }} \\
\left({ }^{\circ} \mathrm{C}\right)\end{array}$ & $\begin{array}{c}\mathrm{P}_{\text {suc }} \\
(\mathrm{kPa})\end{array}$ \\
\hline \multicolumn{2}{|c|}{ Basic MT } & $\mathrm{R} 410 \mathrm{~A}$ & -7 & -2 & 634.40 \\
\hline \multicolumn{2}{|l|}{ Basic LT } & R404A & -25 & -20 & 247.52 \\
\hline \multirow{2}{*}{$\begin{array}{c}\text { Cascaded } \\
\text { LT }\end{array}$} & LT stage & R404A & -25 & -20 & 247.52 \\
\hline & HT stage & R404A & -10 & -5 & 430.76 \\
\hline
\end{tabular}

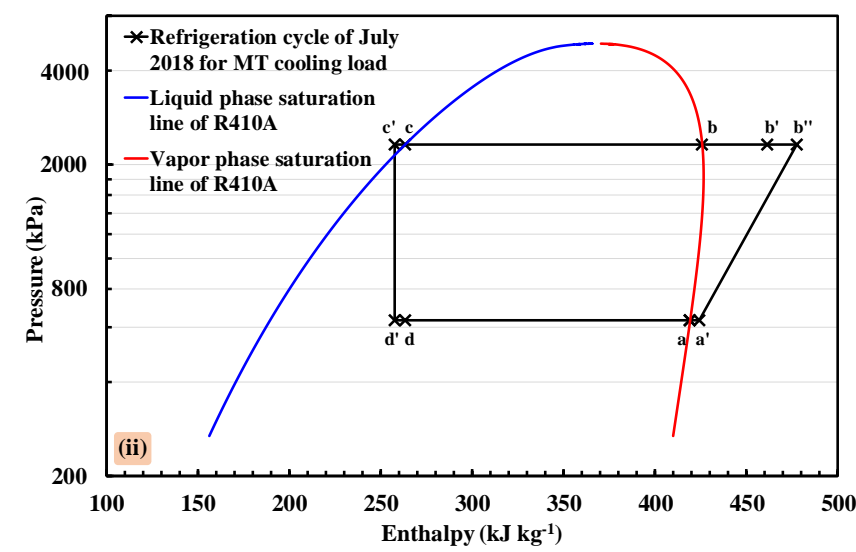

Fig. 3: P-h diagram of MT cooling load in (i) winter, and (ii) summer.
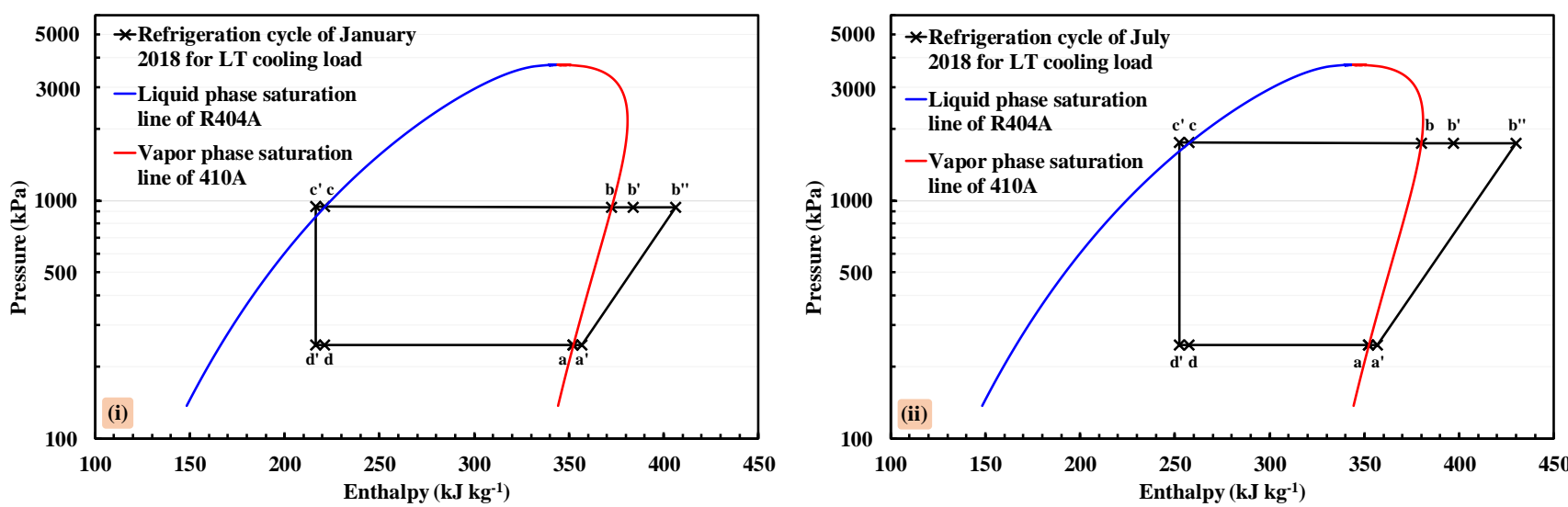

Fig. 4: P-h diagram of LT cooling load in (i) winter, and (ii) summer. 

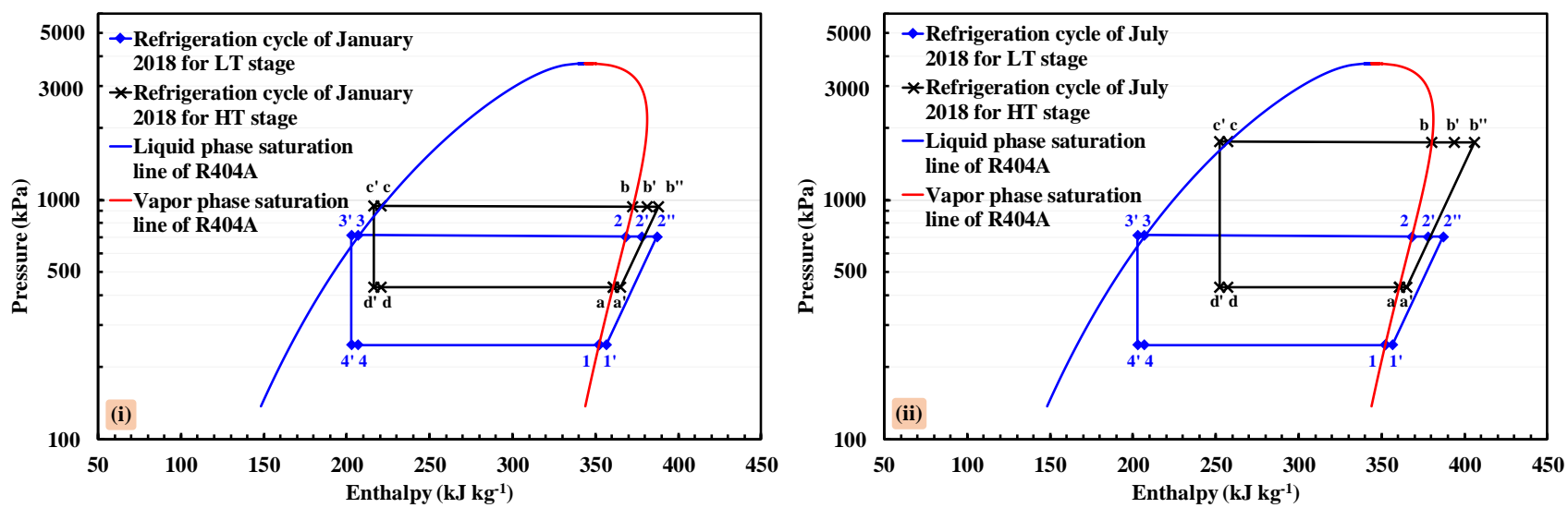

Fig. 5: P-h diagram of LT cooling load for the cascaded system in (i) winter, and (ii) summer.

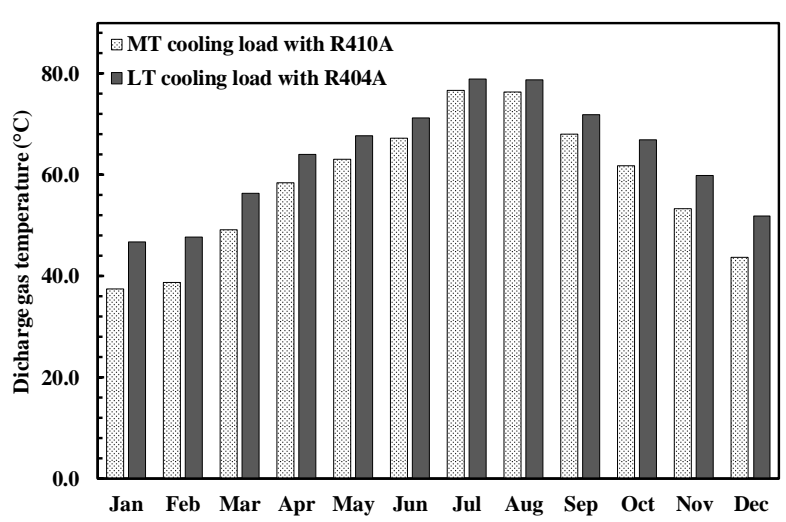

Fig. 6: Comparison of discharge gas temperature from the compressor outlet over the year 2018.

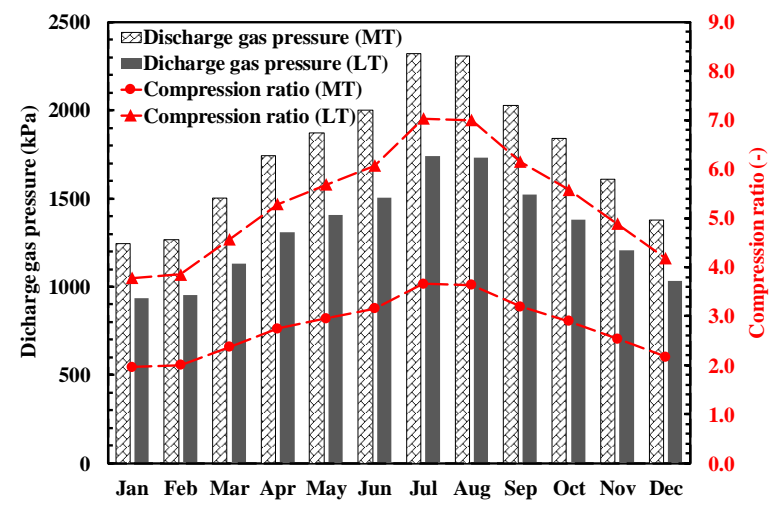

Fig. 7: Comparison of discharge gas pressure and compression ratio over the year 2018.

Since evaporator temperature is fixed regardless of the season, the suction gas pressure is also fixed. It is apparent from the saturation curves that R404A operates at lower pressure than $\mathrm{R} 410 \mathrm{~A}$ for a specific temperature. In this study, the evaporation temperature of R404A is much lower than R410A. Hence, the suction gas pressure is also very low for R404A (Table 4). Moreover, the operation range of the LT refrigeration system is much wider than the MT cooling load for a basic single cycle refrigeration system. The effect of this scenario is reflected in the compression ratio $\left(\mathrm{P}_{\text {dis }} / \mathrm{P}_{\text {suc }}\right)$ plot of Fig. 7 . The variation is from 1.96 to 3.61 and from 3.77 to 7.00 for MT and LT cooling load, respectively. A higher compression ratio reduces the isentropic efficiency of the compressor and also decreases the lifetime. Commonly, the refrigerant of a damaged compressor is not recycled and releases into the environment. That is another reason to increase global warming. Hence, a cascaded refrigeration system is also introduced for the LT cooling load for smooth operation and an increased lifetime of the compressor.

Required mass flow rate of refrigerant depends on the cooling load and operating temperature range. As MT cooling load is greater than LT, Fig. 8 shows higher mass flow rate for MT cooling load. In summer, condensation temperature increases and required mass flow rate of refrigerant $\left(\dot{\mathrm{m}}_{\mathrm{ref}}\right)$ also increases.

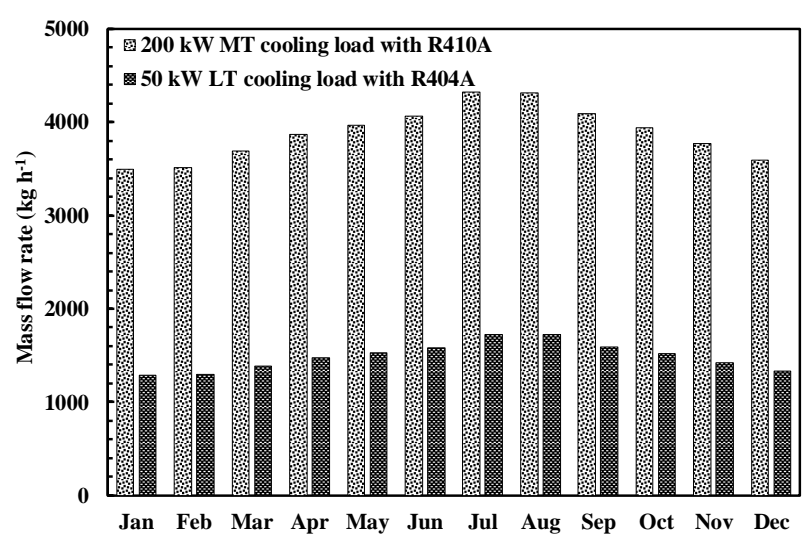

Fig. 8: Comparison of refrigerant mass flow rate over the year 2018.

Condensation temperature is lower in winter and therefore work of compression is also small. Hence, a huge variation in COP is seen from winter to summer which is shown in Fig. 9. Moreover, the COP of LT is much lower because of the huge difference between condensation and evaporation temperature. In this calculation, the isentropic efficiency of the compressor is 
varied for the single cycle system to find the breakeven point with the cascaded system. The results indicate that simple and cascaded refrigeration have similar COP value if the isentropic efficiency is $55 \%$.

Both indirect and direct warming impacts are affected by the ambient temperature. COP decreases with the temperature increment. Hence, electricity consumption is higher in summer which escalates the indirect warming impact. Moreover, higher exterior temperature causes higher discharge temperature and pressure. Thus, the possibility of leakage also increases. In this assessment, a constant leakage rate is considered for each system throughout the year. According to Fig. 10, although the MT cooling load is five times higher than the LT cooling load, TEWI is not proportionally higher. The reason is the higher COP and lower leakage rate of MT cooling load. Furthermore, the cascaded system has two refrigeration cycles and the required refrigerant amount is almost double. However, TEWI of cascaded LT system is slightly higher than the basic LT system. It happens because individual COP of each cycle of a cascaded system is much higher than the basic LT system.

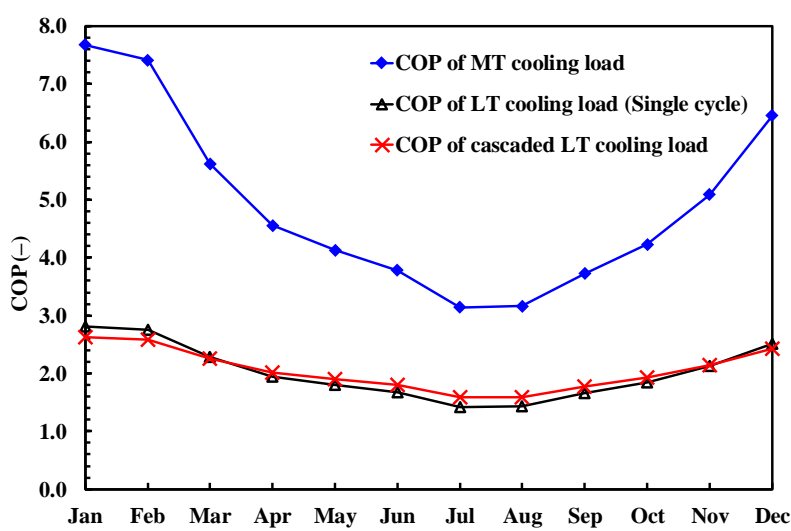

Fig. 9: Comparison of COP over the year 2018.

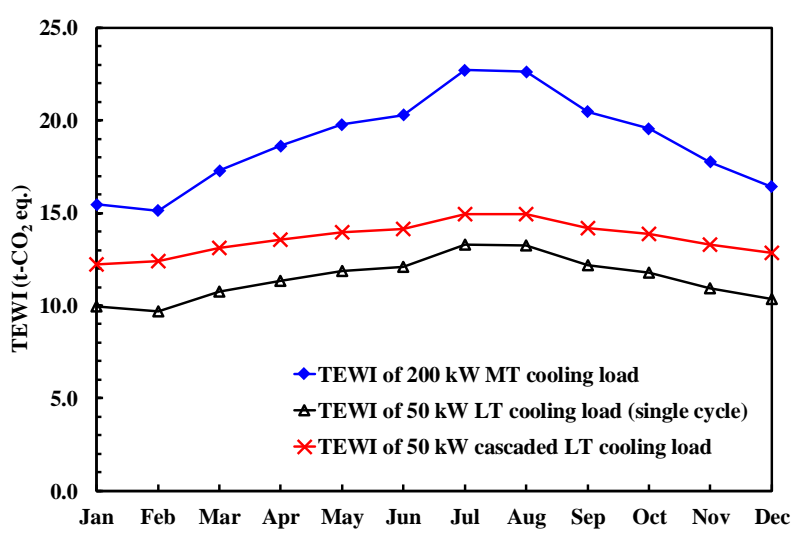

Fig. 10: Comparison of TEWI over the year 2018.

TEWI of past 25 years from the same supermarket is assessed and plotted in Fig. 11. The TEWI pattern reveals an interesting fact that the value has been smaller in the 1990s than the present time. Prior to the Fukushima
Daiichi nuclear power disaster in 2011, more than $25 \%$ of the electricity has been generated from nuclear plants. Nowadays, gradually the $\mathrm{CO}_{2}$ emission factor is decreasing again because more renewable power generation sources are adopted and old nuclear power plants are opening again.

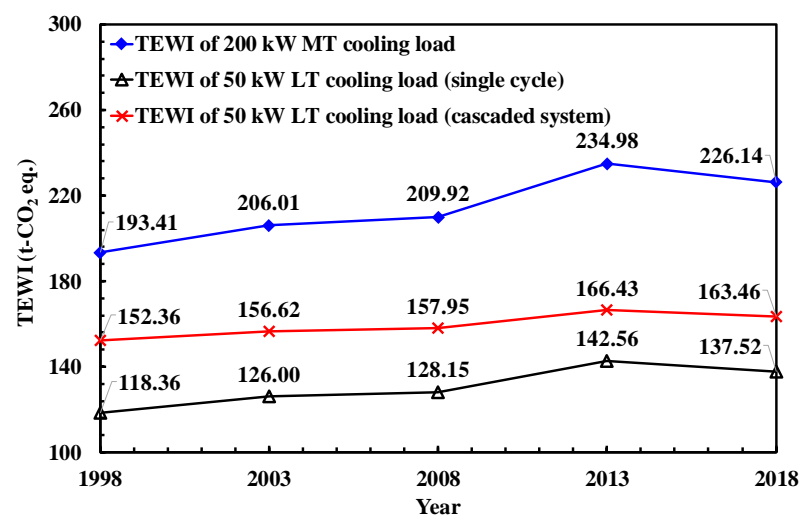

Fig. 11: Comparison of TEWI of past few years from the same supermarket.

\section{Conclusions}

In this work, the variation of performance and warming impact from a supermarket refrigeration system of Tokyo in different months of the year have been assessed. A typical supermarket with $200 \mathrm{~kW}$ MT $\left(\mathrm{T}_{\mathrm{eva}}=-7{ }^{\circ} \mathrm{C}\right)$ and $50 \mathrm{~kW}$ LT $\left(\mathrm{T}_{\text {eva }}=-25{ }^{\circ} \mathrm{C}\right)$ cooling load have been considered. The working fluids are R410A and R404A for MT and LT cooling load, respectively. Since the operating temperature range of the LT cooling load is very wide, a cascaded LT system refrigerant is also introduced.

The analysis indicates that discharge gas temperature is slightly higher for LT cooling load. However, discharge gas pressure is relatively lower for the same LT cooling load. This happens due to the thermodynamic property variation of the refrigerants. Additionally, the compression ratio for MT cooling load is in the acceptable range (1.96 to 3.61) whereas, compression ratio (3.77 to 7.00) is much higher for LT cooling load. Hence, the cascaded system is introduced to keep the compression ratio within the tolerable range. In the cascaded system, the compression ratio of the low temperature stage is 2.84 and varies from 2.17 to 4.04 for the high temperature stage.

COP variations from summer to winter are 3.14 to 7.68 for MT cooling load considering $70 \%$ isentropic efficiency. The overall COP varies between 1.58 to 2.62 for the cascaded system considering same isentropic efficiency. Since the operating temperature range of LT cooling load is wide, it has lower isentropic efficiency. Hence, isentropic efficiency of single cycle LT system is varied to find out the breakeven point with cascaded LT system. The results indicate that, when the efficiency of the basic system reaches $55 \%$ or higher, the basic system has better 
performance than the cascaded system.

TEWI is highest (22.71 t- $\mathrm{CO}_{2}$ eq.) for $200 \mathrm{~kW} \mathrm{MT}$ cooling load in summer because of extreme outdoor temperature. The value is 13.30 and $14.95 \mathrm{t}-\mathrm{CO}_{2}$ eq. for 50 $\mathrm{kW}$ simple and cascaded LT cooling load, respectively. This indicates that the warming impact is very high for per unit LT cooling load. This higher TEWI is because of the huge electricity consumption by the compressor to obtain the target compression ratio. Besides, working fluid R404A, that is used in the LT section, have very high GWP and contribute more in the direct emission.

Performance improvement of the refrigeration system can be achieved by selecting a proper working fluid for a particular operating condition. Modern compressors are designed in such a way that frictional, clearance and other losses are considerably small. Hence, the isentropic efficiency is improved and COP is also high. Leak prevention, proper insulation and efficient heat exchanger design can significantly improve the performance of a system. Moreover, there is a lot of room to decrease environmental impact. Firstly, direct emission can be decreased by choosing proper refrigerant among HFCs, HFOs or natural refrigerants. However, they have certain limitations too. For example, water could not be used where temperature requirement is below zero; $\mathrm{CO}_{2}$ have very high pressure in the operating range; Ammonia possess toxicity, HFOs are expensive and not suitable for all the applications. This assessment gives an insight to the refrigeration system manufacturers of how much environmental impact can occur from their system and which refrigerant could be chosen for a particular application to minimize environmental impact. Secondly, electricity generation from renewable and other clean sources can significantly reduce indirect emission.

\section{Acknowledgements}

The lead author is grateful to Green Asia Education Center of Kyushu University for funding the research work.

\section{References}

1) Vaitkus L., Dagilis V., Int. J. Refrig., 76, 160-169 (2017).

2) Mota-Babiloni A., Navarro-Esbrí J., BarragánCervera Á., Molés F., Peris B., Int. J. Refrig., 52, 21-31 (2015).

3) Pal A., Uddin K., Thu K., Saha B. B., Evergreen, 5, 58-66 (2018).

4) Sawalha S., Piscopiello S., Karampour M., Manickam L., Rogstam J., Appl. Therm. Eng., 111, 170-182 (2017).
“統計・データでみるスーパーマーケット /Statistical data of supermarkets.”: <http://www.jsosm.jp/>, cited 13 February, 2019.

6) "IEA 2018, International Energy Agency. Key World Energy Statistics.”: $<$ https://www.iea.org/countries/Japan/>, cited 13 February, 2019.

7) Kohler J. A., Briley G. C., Clark E. M., Dorman D. R., Duda S. W., Halel D. M., Kuespert D. R., Parker J. T., Reindl D. T., Richards W. V, Schoonover K. M., Troy E. F., Vucci J. I., Westermeyer G. W., Hogan J. F., Jakob F. E., "ANSI/ASHRAE Standard 15-2016; Safety Standard for Refrigeration Systems," 2016.

8) Reddy V. S., Panwar N. L., Kaushik S. C., Clean Technol. Environ. Policy, 14, 47-53 (2012).

9) Lemmon E. W., Bell I. H., Huber M. L., McLinden M. O., NIST Standard Reference Database 23: Reference Fluid Thermodynamic and Transport Properties-REFPROP, Version 10.0, National Institute of Standards and Technology, 2018.

10) Beshr M., Aute V., Sharma V., Abdelaziz O., Fricke B., Radermacher R., Int. J. Refrig., 56, 154-164 (2015).

11) Poggi F., Macchi-Tejeda H., Leducq D., Bontemps A., Int. J. Refrig., 31, 353-370 (2008).

12) Tassou S. A., Grace I. N., Int. J. Refrig., 28, 680 688 (2005).

13) Francis C., Maidment G., Davies G., Int. J. Refrig., 74, 10-19 (2017).

14) Du Z., Domanski P. A., Payne W. V., Appl. Therm. Eng., 98, 61-72 (2016).

15) McIntosh I. B. D., Mitchell J. W., Beckman W. A., ASHRAE Trans., 106, (2000).

16) Davies T. W., Caretta O., Appl. Therm. Eng., 24, 1119-1128 (2004).

17) Memon A. G., Memon R. A., Sustain. Cities Soc., 34, 144-158 (2017).

18) Sun Z., Liang Y., Liu S., Ji W., Zang R., Liang R., Guo Z., Appl. Energy, 184, 19-25 (2016).

19) "Japan Meteorological Agency, Climate of Japan.":

$<$ https://www.data.jma.go.jp/obd/stats/etrn/view/ monthly_s3_en.php?block_no $=47662 \& v i e w=1>$, cited 13 February, 2019.

20) Islam M. A., Srinivasan K., Thu K., Saha B. B., Int. J. Hydrogen Energy, 42, 26973-26983 (2017).

21) "Electricity Review Japan (2018), The Federation of Electric Power Companies.": $<$ http://www.fepc.or.jp/english/library/electricity _eview_japan/index.html $>$, cited 14 February, 2019. 


\section{APPENDIX}
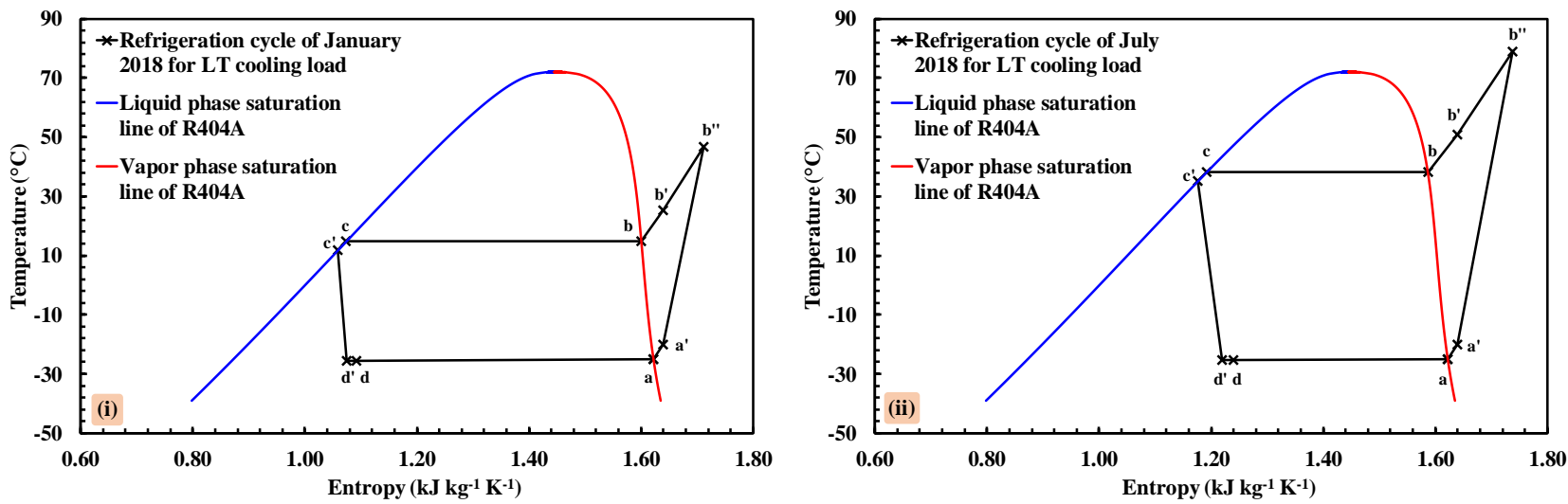

S. 1: T-s diagram of MT cooling load in (i) winter, and (ii) summer.
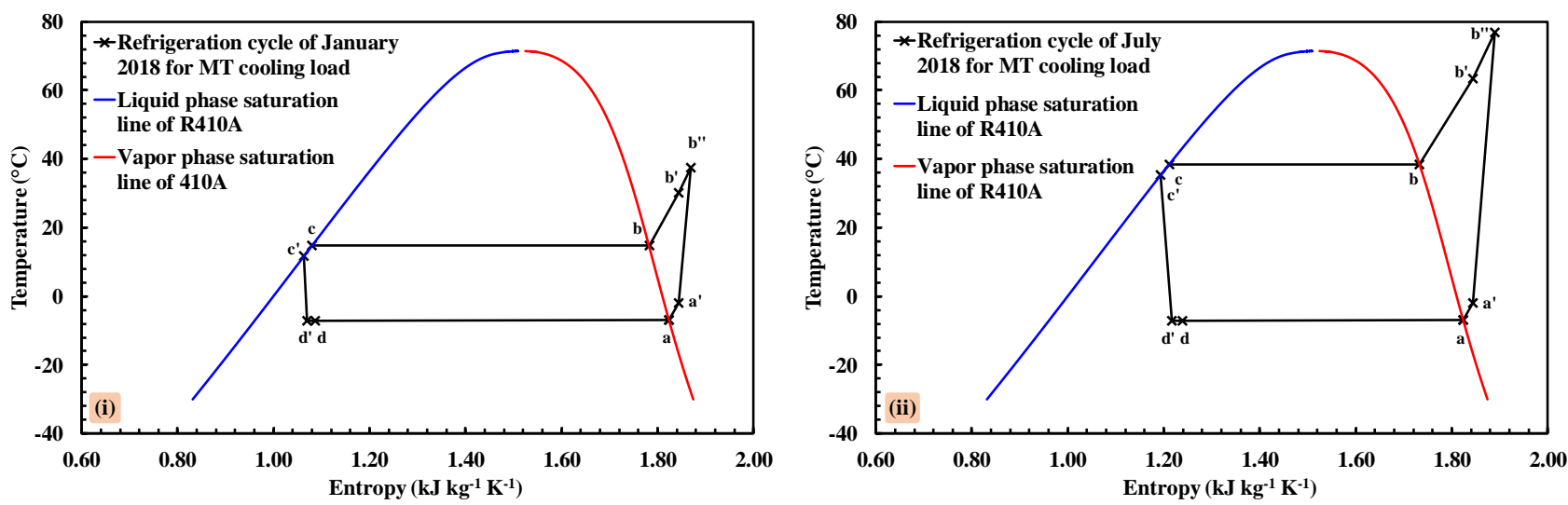

S. 2: T-s diagram of LT cooling load in (i) winter, and (ii) summer.
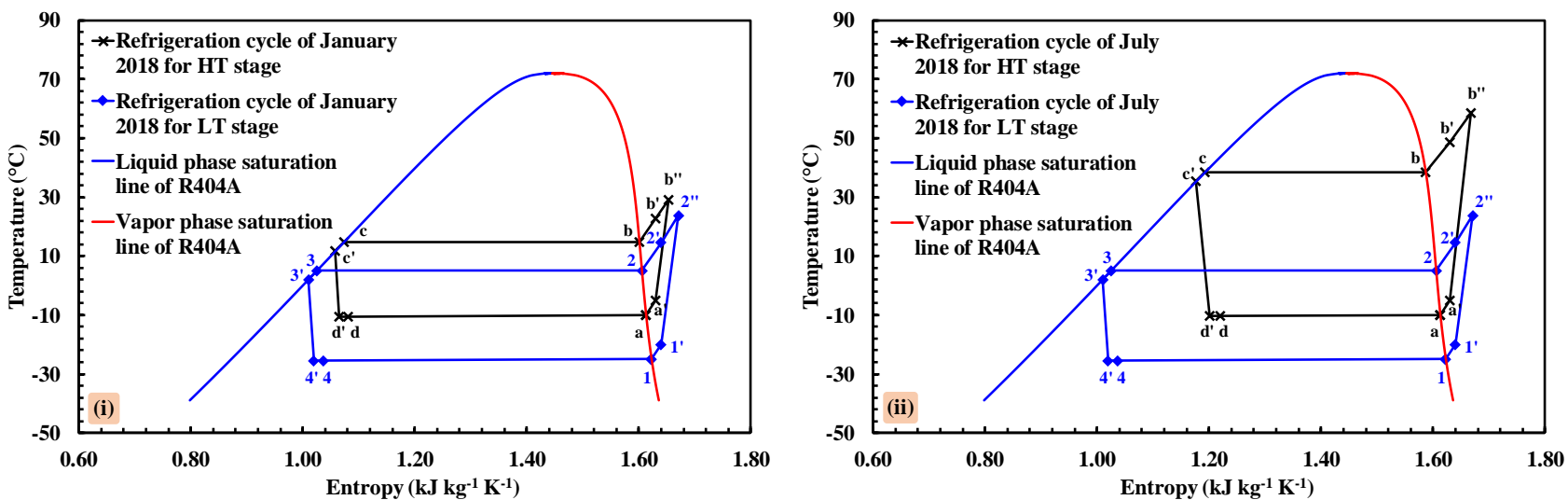

S. 3: T-s diagram of LT cooling load for the cascaded system in (i) winter, and (ii) summer. 